\begin{tabular}{|c|c|c|}
\hline & Int.J.Curr.Microbiol.App.Sci (2021) 10(10): 15-20 & \\
\hline$\frac{}{\text { EXCELLENT }}$ & $\begin{array}{l}\text { International Journal of Current Microbiology and Applied Sciences } \\
\text { ISSN: 2319-7706 Volume } 10 \text { Number } \mathbf{1 0}(\mathbf{2 0 2 1 )} \\
\text { Journal homepage: http://www.ijcmas.com }\end{array}$ & 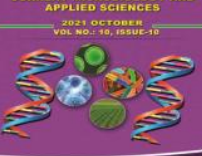 \\
\hline PUBLISHERS & & wwwijcmas.com \\
\hline
\end{tabular}

\title{
A Comparative Study between Cowpea Variety C-152 and Local Variety in Tumakuru District (Karnataka), India
}

\author{
Sunita Kusugal ${ }^{1 *}$, Mukul Baviskar ${ }^{2}$, Sagar Kadao $^{3}$ and Nandini Kelkar ${ }^{3}$
}

${ }^{1}$ BAIF Institute for Sustainable Livelihoods and Development, Tiptur, Karnataka, India

${ }^{2}$ BAIF Institute for Sustainable Livelihoods and Development, Dharwad, Karnataka, India

${ }^{3}$ BAIF Institute for Sustainable Livelihoods and Development, Pune, Maharashtra, India

*Corresponding author

\begin{abstract}
A B S T R A C T
Keywords

C-152, Local variety, Growth,

Yield parameters, higher Income

Article Info

Accepted:

05 September 2021 Available Online: 10 October 2021

Pulses are the second important group of crops after cereals, providing high dietary protein (20 to $25 \%$ ), along with rich supplement of calcium and iron. They play an important role to enhance soil fertility through biological nitrogen fixation and also pass on the benefits to associated non legume and subsequent crops. In Handanakere area farmers cultivate local varieties which are low yielding. A field experiment was conducted in the farmers' fields to know the performance of C-152 cowpea variety with local cowpea variety. The results indicated that $\mathrm{C}-152$ has performed better compared to local varieties in growth and yield parameters. Higher income is generated by the cultivation of $\mathrm{C}-152$ cowpea variety.
\end{abstract}

\section{Introduction}

Karnataka is one of the important pulses growing state in the country. The total geographical area of the state is 191 lakh ha of which 123.11 lakh ha is the net cultivable area. Area under Pulses in the state has increased from 16.21 lakh ha (1990-91) to 23.6 lakh ha (2015-16). Similarly, the production of pulses in state has increased from 5.51 lakh tonnes during 1990-91 to 13 lakh tonnes in 2015-16 (Mohan Kumar et. al. 2020). The important pulses grown in
Karnataka are Redgram, Greengram, Bengalgram, Horsegram, Blackgram and Cowpea. Pulses are the main source of protein for the predominant vegetarian population of India. Besides, they are also used as fodder and concentrate for the cattle. The vital role of pulses in fixation of atmospheric nitrogen needs no emphasis, which infact, is very crucial in light of price hike of nitrogenous fertilizers.

Among arid legumes, cowpea [(Vigna unguiculata (L.) Walp] is of immense 
importance, as it is a multipurpose grain legume extensively cultivated in arid and semiarid tropics. The cowpea is used as grain, vegetables and fodder. Cowpea is grown as a catch crop, mulch crop, intercrop, mixed crop and green manure crop. Cowpea contains maximum protein content and rich in carbohydrates, fats, important minerals, vitamins, phenolic compounds, unsaturated fatty acids and antioxidants (Liyanage et al., 2014). Cowpea contributes to the improvement of soil fertility by the atmospheric nitrogen fixation in the soil (60$70 \mathrm{~kg} \mathrm{~N} \mathrm{ha}{ }^{-1}$ to the subsequent crop) in association with symbiotic bacteria under favourable conditions.

In Karnataka, the crop is grown in an area of 1.5 million hectares with a production of 0.49 million tonnes. The productivity of cowpea in Karnataka is low ( $420 \mathrm{~kg} \mathrm{ha}^{-1}$ ) as compared to the national productivity of $567 \mathrm{~kg} \mathrm{ha}^{-1}$. This clearly indicates there is necessity to identify the reasons for low productivity in India in general and Karnataka in particular. The studies show that high yielding varieties of crop can contribute to an extent towards the improvement of crop yield (Shilpa and Wali, 2018).

Hence, the present study is undertaken in the villages of Handanakere hobli of Chikkanayakanahalli taluk of Tumakuru district. The latitude and longitude are 13.501995, 76.4505243. In these villages, the main livelihood is Agriculture and Livestock. Most of the area is covered by Red sandy soil and coconut plantation. In this area farmers mainly growing Green gram, Cowpea, Finger millet, Little millet, Horse gram, Tur, Sesame, Black gram, Castor, Field bean, Floriculture and vegetables. Rainfall is very low $(400 \mathrm{~mm}$ - $500 \mathrm{~mm}$ ).
The landholding of individuals varies from 0.5 acres to 10 acres. Major of the farmers are using local seeds since from last 5-8 years, which are low yielding i.e. below 5 to 6.25 quintals per hectare. Seed rate of local variety is also high. It varies from 25-37.5 kgs / hectare. Keeping the above points in view, a comparative study was taken with local existing varieties and improved varieties (C152).

\section{Materials and Methods}

Research trail was conducted in the selected 41 farmers' fields. All the farmers have cultivated C-152 as well as local cowpea varieties. Observations on plant height $(\mathrm{cms})$, Number of branches, No. of pods, pod length (cms) and yield (quintal) per hectare were made. The pooled data was statistically analysed. Z- test (Two-sample Assuming Equal variances) was done.

\section{Results and Discussion}

The results are presented in the Table 1, for Plant height (cms), number of branches \& pods, length of the pod (cms) and grain yield (qtls). Both the varieties showed marked differences for growth and yield parameters. C-152 has recorded significantly highest plant height of $48.89 \mathrm{cms}$ compared to local varieties. Also more number of branches were recorded in C-152 variety (8.71). Whereas 5.94 branches were observed in local varieties. It was observed and recorded that pod length and number of pods were maximum in the C152 variety (14.87 $\mathrm{cms} \& 36.77$ ) compared to local varieties $(9.50 \mathrm{cms} \& 24.25)$ respectively. Significantly higher yield per hectare is obtained in the $\mathrm{C}-152$ variety i.e. 8.21 qtls / ha whereas it is 5.15qtls / ha in the local variety. 
Table.1 Comparison between Improved variety (C-152) and local variety on Growth and Yield Parameters

\begin{tabular}{|c|c|c|c|}
\hline$\underbrace{\text { Varieties }}_{\text {Parameters }}$ & C-152 & Local variety & $\begin{array}{l}\mathrm{z} \text { test: } \\
\text { Two-Sample Assuming } \\
\text { Equal Variances } \\
\\
P(T<=t) \text { two-tail }\end{array}$ \\
\hline Plant height (cms) & 48.89 & 35.06 & $2.00^{-11}$ \\
\hline No. of branches & 8.71 & 5.94 & $3.83^{-05}$ \\
\hline Length of the pod (cms) & 14.87 & 9.50 & $2.48^{-12}$ \\
\hline No. of Pods & 36.77 & 24.25 & $1.25^{-06}$ \\
\hline Yield (qtls / ha) & 8.21 & 5.15 & $9.97^{-42}$ \\
\hline
\end{tabular}

(Significant at $5 \%$, highly significant at $1 \%$ )

Table.2 Economics of C-152 \& Local variety per hectare

\begin{tabular}{|c|c|c|c|}
\hline Sl. No. & Details & C-152 (Rs.) & Local variety (Rs.) \\
\hline $\mathbf{1}$ & Cost of cultivation & 18325 & 18937 \\
\hline $\mathbf{2}$ & Gross income & 41000 & 25750 \\
\hline $\mathbf{3}$ & Net Income & 22675 & 6812 \\
\hline
\end{tabular}

Fig.1
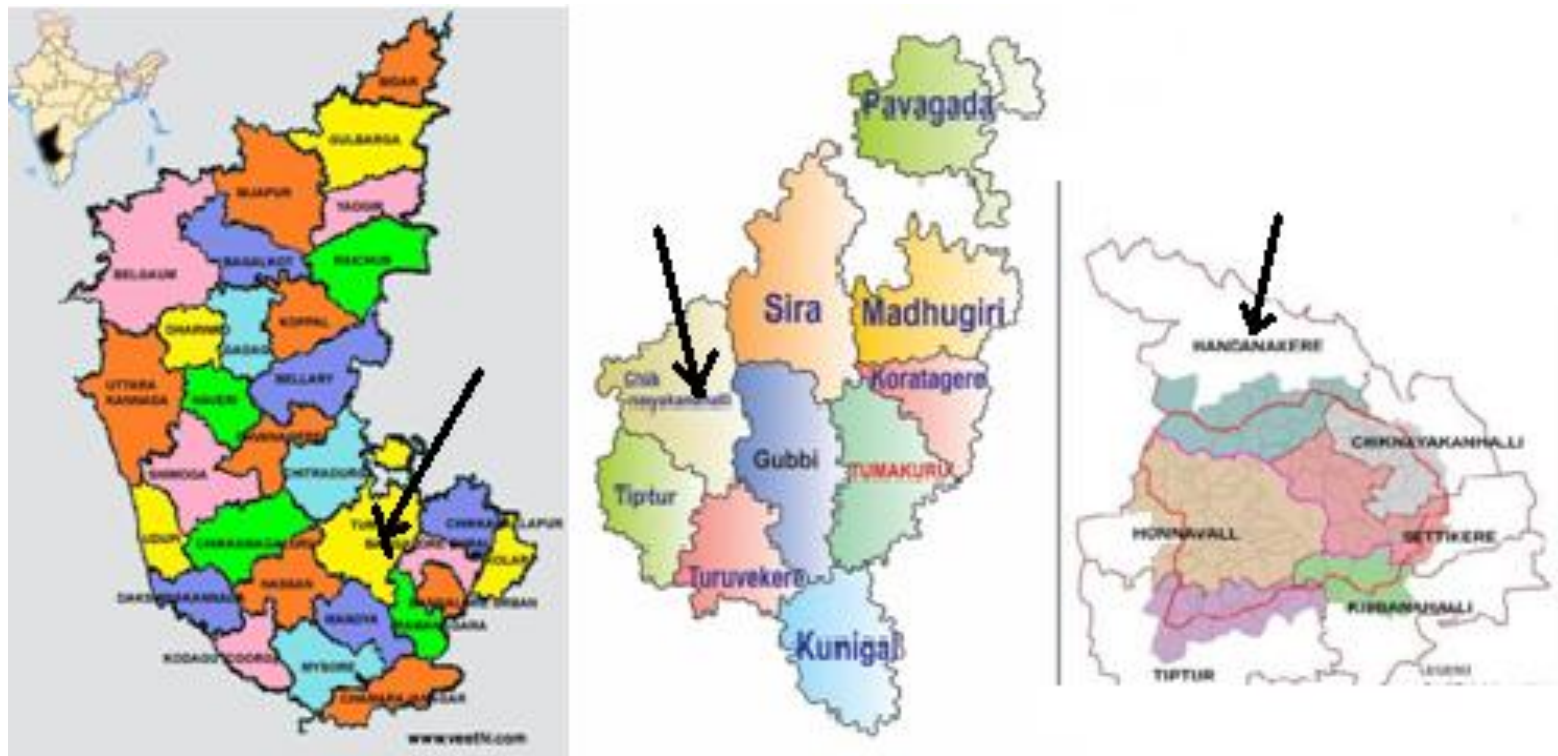
Fig.2 Comparison between Growth and Yield parameters of C-152 and Local variety

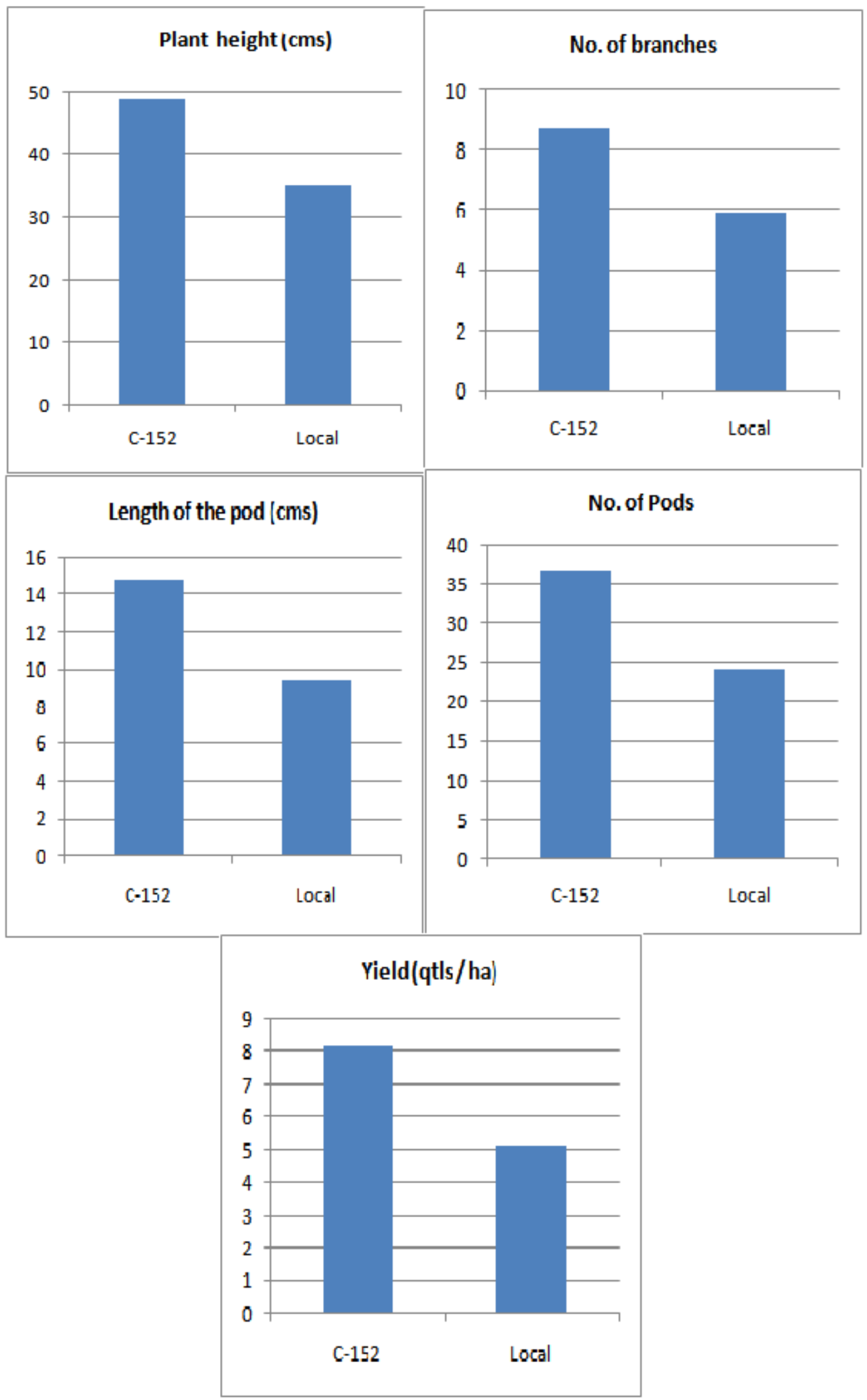


The economics of the cultivation of C-152 and local varieties is given in the Table -2 . The cost of cultivation is minimum in C-152 variety compared to local varieties. Because high seed rate is used in local varieties i.e. $31.25 \mathrm{kgs} /$ hectare whereas, in improved varieties it is $18.75 \mathrm{kgs} /$ hectare. The higher net income of Rs. 22,675/- is obtained by the cultivation of C-152 cowpea variety, which is more than 3 folds compared to local cowpea varieties.

Superior growth parameters namely plant height, number of branches, number of pods and length of the pods have resulted in higher yield. According to Singh et al., (2018) the minimum grain yield, biological yield and Stover yield were recorded because of lower plant population at harvest and decrease yield attributing characters namely pods / plant, grain per pods etc due to low temperature and soil moisture, which restrict plant growth and development. Unless the plant has an adequate biomass it cannot be expected to yield high. The data clearly reveals that the biomass is one of the important factors which is related with seed yield. Plant canopy which is formed by leaf number, leaf area and plant height show a relationship with the total biomass with respect to plant height only. The results are also supported by Shilpa and Wali, (2018). Yield per plant is determined by other yield components namely number of pods per plant, number of seeds per pod, 100-seed weight. This improvement was mainly due to significantly higher photosynthetic efficiency, which might have led to formation of more number of pods per plant and number of seeds per pod. Higher seed yield with KM-5 was mainly a consequence of more number of pods per plant which in turn was due to higher plant height and more number of branches per plant (Parameshwarappa and Lamani 2005).

From the present study it can be revealed that use of higher seed rate do not attribute to the higher grain yield. And the study evidenced that by using improved variety seeds for cultivation leads to higher income.

The use of improved variety seeds of Cowpea has resulted in higher biomass i.e. plant height and number of branches contributed to higher seed yield and in turn higher income.

\section{Acknowledgement}

Authors are thankful to Prerna (Mahindra and Mahindra) project for support to conduct the study. Authors are thankful to BAIF Institute for Sustainable Livelihoods and Development - Management for continuous support throughout the project. And also authors are thankful to Field guides Ms. Shwetha, Ms. Pallavi, Ms. Manjula, Ms. Sukanya \& Ms. Nandini for helping in field data recording.

\section{References}

Liyanage, R., O. S. Perera and R. Sivakanesan. 2014. Nutritional and antioxidant content of commonly consumed cowpea cultivars in Sri Lanka. Journal of Food Legumes 27: 215-217.(Internet search)

Mohan Kumar, B., Reddy, B. S., and Goudappa, S. B. 2020. Growth performance of pulses in karnataka, India. Int.J.Curr.Microbiol.App.Sci (2020) 9(2): 2272-2280 2272. Original research article https://doi.org/10.20546/ijcmas.2020.9 02.257

Parameswarappa, S. G. and Kumar D. Lamani 2005. Identification of promising high yielding cowpea varieties for northern transitional zone of karnataka under rainfed conditions. Karnataka J. Agric. Sci., 18(1):(133-134).

Shilpa, H. D. and Wali, S. Y. 2018. Performance of cowpea (Vigna unguiculata) genotypes during 
gummer under different levels of phosphorus Application, Int. J. Pure App. Biosci. 6(1): 1190-1194. doi: http://dx.doi.org/10.18782/23207051.5191

Singh, M. B., Singh, A. K., Lala, I. P and Devi M. B. 2018. Study on comparative performance of cowpea in rice fallows areas as influence by dates of sowing in ribhoi district of Meghalaya. Indian Journal of Hill Farming. June 2018, Volume 31, Issue 1, Page 23-29. (Internet search)

\section{How to cite this article:}

Sunita Kusugal, Mukul Baviskar, Sagar Kadao and Nandini Kelkar. 2021. A Comparative Study Between Cowpea Variety C-152 and Local Variety in Tumakuru District (Karnataka), India. Int.J.Curr.Microbiol.App.Sci. 10(10): 15-20.

doi: https://doi.org/10.20546/ijcmas.2021.1010.003 